\title{
Why Political Parties Colonize the Media in Indonesia: An Exploration of Mediatization
}

\author{
Muhammad Thaufan Arifuddin`
}

\begin{abstract}
Mediatization has become more relevant in exploring relations between media and politics in post-Suharto Indonesia. However, the media's role as the fourth estate of democracy has been hijacked by wealthy politicians and political parties. As a result, most mainstream media have failed to enhance public debates democratically. Based on existing mediatization literature, politico-economy analysis, and data collected through extensive in-depth interviews and relevant documents in the 2013-2015 period, this article theoretically aims to develop the mediatization concept and explore the degree of mediatization of politics in contemporary Indonesia.
\end{abstract}

Keywords:

mediatization; mediation; media logic; political logic; media democratization.

\section{Abstrak}

Mediatisasi menjadi lebih relevan dalam menjelajahi relasi media dan politik di Indonesia paska Soeharto. Namun, media sebagai pilar keempat demokrasi telah dibajak oleh elit dan partai politik oligarkis. Akibatnya, media mainstream gagal mendorong perdebatan publik secara demokratis. Berdasarkan literatur mediatisasi dan analisis ekonomi-politik, data wawancara mendalam serta dokumen relevan pada periode 2013-2015, artikel ini secara teoritis bertujuan mengembangkan konsep mediatisasi dan mengekplorasi tingkat mediatisasi politik di Indonesia kontemporer.

\section{Kata Kunci:}

mediatisasi; mediasi; logika media; logika politik; demokratisasi media.

\section{Introduction}

Mass media and social media in postSuharto Indonesia have significantly played a central role in promoting the democratic public sphere and monitoring the ruling government. It should be noted that the media have essentially been disseminating information, constructing public opinions and facilitating citizens and politicians at the local and national levels for

\footnotetext{
- Lecturer of Department of Communication Science, Faculty of Social and Political Sciences, Universitas Andalas. Email: thaufanmalaka@gmail.com.
}

political aspirations, public debates, and even for collective actions, participatory culture, and civic engagement among netizens and civil society activism (Arifuddin, 2014; Nugroho \& Syarif, 2012 Lim, 2013; Nugroho, 2007, 2008). Social and political activism have been covered by the media and have gradually led to more democratic, transparent and responsible governance.

Since the late 1990s until the mid-2010s, the political debates and social activism that had been widely covered by the media, either through traditional mainstream media or 
new internet-based media, confirmed the contestation of media and political logic in Indonesia. In the post-1998 democracy, a variety of public debates have radically advanced Indonesian democracy in the sense of promoting civil politics and enforcing democratic laws and regulations that indicate democratic transition and consolidation processes such as freedom of press, broadcasting reform, and election reform (Armando, 2011; Harris and Forresti, 2011). This situation continues into the current era of President Joko Widodo's populism alongside the social movement played mostly by lower class groups and civil society organizations by using both mainstream media outlets and internet-based media (i.e., online and social media)to foster more democratic agendas in curbing corruption and criticizing oligarchs and cartel parties (Mietzner, 2015; Aspinall, 2013). This period ultimately indicated not only the contestation between reformists and conservative actors based on complex power relations, but to some degree, it also initiated the intensive process of mediatization of politics wherein media interaction with politics became more powerful and dominating in contemporary Indonesia. Mediatization refers to a change process through which the media have become increasingly influential.

The emerging revolution of information and communication technologies (ICTs) such as the internet and social media in the last decades has triggered mediatization of society and politics. As a result of this globalization trend, political realms are intensively more mediatized. Most of the media in terms of medium per se and contents have creatively transformed into integrated parts of society, culture, and politics, and are therefore intensively interplayed against each other (Hjarvard, 2008; Stromback, 2008). ICTs even sparked the information era that led to the rise of network society and ultimately vibrant political and cultural sensibilities of present social movements (Castells, 2010).
Politically speaking, the media in Indonesia`s Post-1998 democracy have hardly challenged the domination of political institutions and actors, hence it is not fully promoting its logic as the fourth estate of democracy and tends to compromise with oligarchic political parties and actors linked to the post-authoritarian legacy instead. This Indonesian case is not unique as similar cases can be observed to occur globally in a number of countries as a result of the development of the media sector's interconnectedness with oligarchic networks of the transnational state. Critics indeed blamed the media for distorting the democratic processes in American politics regarding media coverage of the LewinskyClinton affair, the 1997 electoral victory of Labour leader Tony Blair in the United Kingdom, the 1989 victory of Fernando Collor de Mello in the Brazillian presidential elections, and the performance of Silvio Berlusconi, a media tycoon, in the 1994 Italian general election (Mazzoleni \& Schulz, 1999).

In Indonesia, political parties such as Golkar and Nasdem have mainly been determining mainstream media's opinions during political events since the second term of President Susilo Bambang Yudhoyono (SBY) until today. Mieztner (2015) mentioned this period as the decline of democracy after Reformasi. Even worse, those two political parties have continuously been occupied by powerful elites, e.g. Abu Rizal Bakrie and Surya Paloh who own several media such as TV One and Metro TV, and they consequently utilized those media in favor of their interests leading to useless debates and disproportional political control by the media (Lim, 2012). They colonized public opinion favoring certain political parties and benefiting a number of elites to win the national and local elections and contestation. Regarding the matter, Manuel Castells states that in the current era, financial flows take control of media empires that influence political processes and they are 
the privileged instruments of power (Castells, 2010).

Most people have been silenced over such form of colonization because the operation process is subtly hegemonic. In this sense, this interference ultimately contributed to the public's decreasing access to information, the underrepresentation of certain groups, and the making of media fantasy reality afterward (Lim, 2012). Nevertheless, a few critical citizens, netizens and CSOs have creatively taken democracy back and criticized this colonization in the recent offline and online deliberation through social media and civil society activism, productive debates, political mobilization, etc. They have not only criticized political parties and oligarchic processes but also offered alternative perspectives of political ideas and practices.

This article would like to address the question of why political parties have vested interests in controlling the post New Order media. It is consequently necessary to explore the political economy of the media since the last period of Suharto's regime until today's post-1998 democracy and the degree of the mediatization of politics involving the interaction between the political parties and the media to determine not only the dynamics of power relations but also to track current media development in Indonesia. The significance of this article would thus contribute to not only introducing the mediatization concept in terms of integrating media, culture, and politics to enrich the horizon of political and communication studies in Indonesia, but also to initiating and spurring particularly dynamic mediatization debate in Indonesia which still has not been properly addressed in the Indonesian literature. This article employs literature of politics and media communication studies based on data from semi-structured interviews and relevant documentation and media contents from internet-based media such as youtube, online and social media within the period of 2013-2015.

\section{Theoretical Framework}

\section{A Discussion on the Mediatization of Politics}

The mediatization concept has been incredibly elaborated by a number of scholars (Hjarvard, 2008; Schulz, 2004; Stromback, 2008) and it denotes an inherently processoriented concept of intertwining media, politics, culture, modernity, and social change. This term historically refers to a process where a group of people increase their influence at the expense of others (Strömbäck \& Dimitrova, 2011). However, as an academic term it was initially applied to media's impact on political communication and other effects on politics, and it was initiated by the Swedish academic Ken Asp (1986) to describe mediatization of political life as a process whereby a political system to a high degree is influenced by and adjusted to the demands of the mass media in their coverage of politics. In the same light, Altheide and Snow $(1979,1988)$ call for an analysis of social institutions-transformedthrough-media, and Mazzoleni and Schulz (1999) applied the concept of mediatization to media's influence on politics (Hjarvard, 2008).

To precisely understand the term mediatization, a separation between the concept of mediatization and mediation is necessary. This concept comes close to the concept of mediation as the larger process of media influence on the social world which has also been elaborated by some scholars such as Altheide and Snow, 1988; Bennett and Entman, 2001; Couldry, 2008; Davis, 2007; Nimmo and Combs, 1983; and Silverstone, 2007. According to Livingstone, scholars from continental Europe prefer the term mediatization whereas American and British scholars prefer the term mediation. However, mediatization and mediation are not synonymous because mediation has another meaning as the rather neutral process of transmitting messages (Strömbäck \& Dimitrova, 2011). 
This concept gains a more contemporary political perspective under the mediatization of politics term elaborated by Jespers Stromback through which the media have become increasingly independent from politics and through which political actors and institutions have become increasingly dependent on the media. Although mediatization of politics has a multidimensional concept, it could be identified through four dimensions which pertain to politics and media influence (Stromback \& Van Aelst, 2013).

The first dimension is related to the extent to which themedia constitute the mostimportant source of information and communication. The second dimension describes the media's independence from other social institutions, not least political institutions. The third dimension is concerned with media content and the extent to which media content is governed by media logic or political logic. The last dimension explores political actors and the degree to which they are governed by media logic or political logic (Strömbäck \& Dimitrova, 2011; Stromback, 2008). For this purpose, those four stages of mediatization of politics theory is not only relevant but also necessary to be cultivated in Indonesia.

\section{The Mediatization of Politics in Indonesia`s Post-1998 Democracy}

Mediatization is currently a relevant perspective in understanding the intensive relations between media and politics in contemporary democracy (Stromback, 2008) including in the Indonesian context and situation. This phenomenon will be the rational consequence of the development of information, communication and technology throughout the world and Indonesia as well. The trend has already started since Suharto's era in which it began to intensively develop following Suharto's resignation from his authoritarian regime and even more so in the advent of democratic governances that have been promoting media freedom and more media industry since the Habibie administration in 1998 until today`s Jokowi era.

This mediatization process in Indonesia could be better explained by understanding the complex processes of media development under the Suharto era that led to present media performance. It can be critically said that the media industry is successively related to the post-authoritarian legacy in which status quo elites who adopted the Indonesian New Order mannerism and ideas are politico-economically still in power contestations hand in hand with colonization of the media sector in the pursuit of other areas of power (Robinson \& Hadiz, 2004). That is why the politico-economy analysis of the media industry regarding the final period of the New Order and the present media sector is essentially being explored as a foundation in interpreting more mediatized politics in post-1998 democracy.

Broadly speaking, mediatization is an assortment of complex political communication processes that explore relations between politics and media by taking political and media logic into account in favor of democracy. Despite its connection, this term should be distinguished from the concept of mediation in which politics occupies the media to spread political information and communication between the governors and the governed. This theoretically relates to the elaboration of Ben Anderson (Anderson, 2006), Walter Lippman (Lippman, 1922) and a number of scholars in their recent studies to politically describe media contribution and intervention toward the imagination of nation-state and construction of public opinion (Stromback, 2008).

The stage of the mediation of politics tends to justify the power of ruling elites leading to critical criticism among left-leaning intellectuals by using political economy analysis to challenge media ownership and also question the degree of media autonomy. In this sense, mediation of politics since Suharto's 
regime is truly relevant and becomes a part of the long mediatization processes that seek to enhance the potential democratic role of the media.

Nonetheless, the first three phases of mediatization of politics are relevant and could likely explain the political situation and Indonesian media outlets in post-authoritarian Indonesia. Mediatization mainly discusses the contestation between political logic and media logic in the public sphere. Indeed, the first stage of the mediatization process is approximate to the mediation process of Indonesian politics whereby media became the dominant source of political information that could be easily intervened by Suharto and his political cronies. The Indonesian context had been absolutely mediated during the Suharto era through TVRI, RRI, and Private television networks since those media were politically controlled by Suharto and his cronies.

The second process pertains to the attempt of the media in Indonesia to survive and become more professional and also more commercialized-pragmatic with the advent of the Reformasi (reform) era in 1998. As a consequence, both conservative and reformist political actors improved their capacities and skills to adapt to pragmatic media logic, but those actors to some extent remained politically subordinate under media autonomy. The period from the Reformasi era in 1998 up to the advent of the first new democratic election in the postauthoritarian regime in 1999 also reflected this stage with the emergence of hundreds of media news; print media, electronic media, and internet-based media.

Since 1999-2015, the third process of mediatization of politics had been gradually approaching and determining political realms in Indonesia in terms of media contents, political visions, and the representation of spin doctors in political events which was more dominant elsewhere under the coming age of instant communication (Brewin, 2002; McNair, 2007).
Spin doctors could be maintained and played by pollsters, journalists, retired politicians, officials, campaign and communication consultants, and academicians in today's public relations democracy (Louw, 2005). The practice of spin doctors has also been incredibly appearing and operating more dynamically, either independent or full of vested interested, during the Indonesian elections since 1999 until today. Therefore, these various actor shave in a way contributed to promoting more advanced democracy in Indonesia by conducting trusted polling, enforcing law, transparency, and more participation in the electoral democracy. However, they also created hurdles which held democracy back in the process since they totally manipulated polling and exploited some candidates or being exploited themselves by obsessive candidates who provided money through corruption as can be seen in some private television networks, Youtube videos and many other social media outlets today.

Moreover, polling organizations that have emerged post reform, transformed Indonesia's electoral democracy to not only be more transparent and qualified in controlling and watching any elections but also to be more paradoxical in which some polling organizations, for example Pusat Kajian Kebijakan dan Pembangunan Strategis (Puskaptis), tended to manipulate quick count to support Prabowo Subianto and Hatta Rajasa in the 2014 presidential election. Whereas Centre for Strategic and International Studies (CSIS), Lingkaran Survei Indonesia (LSI), and Saiful Mujani Research Center (SMRC) showed different quick count results that are regarded to be more trustworthy since their organizations are deemed more credible and capable.

Some notable polling organizations in Indonesia are Resource Productivity Center (RPC), International Foundation for Election Systems (IFES), LP3ES, Litbang Harian Kompas, and KPP-Lab Politik UIin the 1999 election, Lembaga Survei Indonesia (LSI), Pusat Pengkajian 
Islam dan Masyarakat (PPIM), Soegeng Sarjadi Syndicated (SSS), Danareksa Research Institute (DRI) in the 2004 election, and many more media, think tanks, and polling organizations under Perhimpunan Survei Opini Publik Indonesia (PERSEPI) and Asosiasi Riset Opini Publik (AROPI) during the 2009 and 2014 elections such as Indonesia Research Center (IRC), Pusat Kajian Kebijakan dan Pembangunan Strategis (Puskaptis), Lembaga Survei Nasional (LSN), and Jaringan Suara Indonesia (JSI), Litbang Kompas, Lingkaran Survei Indonesia (LSI), Indikator Politik Indonesia, Populi Center, Centre for Strategic and International Studies (CSIS), Radio Republik Indonesia (RRI) and Saiful Mujani Research Center (SMRC).

Spin doctors used TV channels to spread their political opinions since TV is the most popular media and it is massively consumed by the Indonesian people by 91.68 in 2012 in order to influence large audience. Polling organizations and think tanks at the time played central roles to emphasize bandwagon and underdog effects in any political events. They ultimately determined public opinion in the mass media especially in private TV channels despite the presence of some investigative media such as Tempo and Kompas that are relatively more autonomous in terms of news reporting and opinion formation. For example, during the 2014 election, TV One, along with some polling organizations such as Puskaptis, vulgarly supported Prabowo Subianto and Hatta Rajasa by covering their candidacy more and partly manipulating the quick count results in their programs which contradicted independent journalism principles as well as autonomous critical thinking that we can frequently observe in and is commonly utilized by Kompas and Tempo along with a number of capable pollsters such as LSI, SMRC, CSIS, etc.

Polling organizations are strictly regulated by a legitimate organization called Persepi (Perhimpunan Survei Opini Publik
Indonesia, Association of Public Opinion Survey). However, some polling organizations such as Indonesia Research Center (IRC), Pusat Kajian Kebijakan dan Pembangunan Strategis (Puskaptis), Lembaga Survei Nasional (LSN), and Jaringan Suara Indonesia (JSI) vulgarly supported the candidacy of Prabowo Subianto and Hatta Rajasa in the 2014 election. They subsequently released their quick count results and it consequently made Prabowo-Hatta to confidently declare their victory by quick count in TV One ${ }^{1}$. However, PBHI sued these pollsters for the manipulation ${ }^{2}$ and also Persepi strictly dismissed Puskaptis and JSI from the organization. ${ }^{3}$

In this third phase of mediatization of politics, the spin doctors, think tanks and polling organizations were political actors and institutions and they truly created pseudo politics and fantasy realities for supporting their candidates or any elites' interests. Those spin actors and institutions in a number of elections in post-reform Indonesia represented the interests of the elites and political parties throughout the mainstream media owned by wealthy politicians such as Abu Rizal Bakri, Surya Paloh, and Harry Tanusudibyo. They speak in the mainstream media in order to set political agenda that would lead to meet the interests of political parties. However, other alternative media operated by critical activists and free writers attempted to respond by opposing this situation and promoting media logic of the last mediatization and public supremacy by using internet-based media such as indoprogress.com, jakartabeat.net, and the latest new comers: Islambergerak.com and qureta.com.

\footnotetext{
This victory`s declaration by quick count can be seen here https://www.youtube.com/watch?v=JbKcGdh6XVw

2 This issue is accessed here https://www.youtube.com/ watch? $\mathrm{v}=7 \mathrm{lrFtsHhA68}$

3 This can be seen here https://www.youtube.com/ watch?v=9FQQKdRSAK0
} 
As a result, critically thinking stakeholders such as public intellectuals, CSO activists, student organizations responded to those politicizations by spreading true information based on cover both side journalism, critical thinking and democratic principles to keep democracy on the right track. They achieved this by criticizing political parties, elites, spin doctors and the mainstream media via alternative internet-based media such as online and social media and also by condemning mainstream media for not being valid and completely colonized by oligarchic elites and their political parties as well as frequently being the mouthpiece of oligarchic networks in political events. Politically speaking, every political group and party are supposed to promote their candidates, ideas, identities and stance within the political reality and discourse in Indonesia to radicalize democracy (Laclau \& Mouffe, 1988; Norris, 2006), but unfortunately they tended to glorify racism and enhance sectoral interests. Thus, each group in Indonesia needs to radically consider their involvement and participation in the long term political practice and discourse with a more rational and visionary approach to weaken and eliminate oligarchic networks and also to promote a more advanced democracy in Indonesia.

The last stage of mediatization has not taken place in contemporary Indonesia. But it is ideally and clearly described as the process in which media carry out the supremacy of media logic in promoting democracy from, by, and for the public. Any political actors and institutions are expected to adapt, adopt, and internalize the media logic as the foundation of democracy and regard it as the mind of the public. Media would ultimately supervise political dynamics through their professionalism and worthiness.

Civil actors support this media logic so that the media are able to strategically and ideally play their role. Any political actions that ignore media logic would be a failure since media are on the right track as the guardian and fourth estate of democracy that is based philosophically on the foundation of rational, critical thinking, journalism principles and public support that promote equality, freedom, and public interests. In the 2014 Indonesian presidential election case, Prabowo Subianto and Hatta Rajasa under their allied parties and oligarchic elites blatantly delegitimized and manipulated media principles and power for their vested interests, particularly by exploiting TV One for their candidacy and campaign since TV One is owned by Abu Rizal Bakri, Prabowo`s supporter. Whereas, Joko Widodo and Jusuf Kalla along with their supporters and volunteers claimed victory and garnered sympathy in the 2014 campaign and election from the public and the media since they were well-respected and adapted to media logic. In the end, media truly became more political and powerful along with other social and political movements by consistently promoting media logic not for the interests of others but for the sake of democracy as observed in media such as Kompas, Tempo, and in organizations such as Indonesian Corruption Watch, Lembaga Bantuan Hukum, Transparency International Indonesia, Nahdatul Ulama, Muhammadiyah, etc. Nevertheless, this last perspective is yet to be fully achieved in Indonesia's contemporary democracy.

Regarding this apex of political mediatization, Indonesia has not fully experienced this situation by considering the roles of mainstream media. Anumber of reasons are, firstly, Indonesia has hardly escaped from the post-New Order legacy such as oligarchic nodes and networks that remain in power to pursue economic profit (Robinson \& Hadiz, 2004). Secondly, Indonesia media have yet to fully advance into becoming democratic actors comparable to media in western developed countries in conducting investigative reports, challenging regimes and mostly being part of any reform and movement. 
Finally, the last phase of mediatization is still in its infancy in the Indonesian context with some conditions that ought to be fulfilled such as the enhancement of democratic ideas and practices, the commitment of political actors and institutions, the improvement of media performance, and the full support from prodemocratic actors to fight against colonization over the media. This last mediatization process could realistically transform the current Indonesian democracy.

\section{Method and Data}

This article employs a qualitative approach to interpret and explore challenges of media democratization in Indonesia. The qualitative method is considered relevant since it can interpret socio-political phenomena and historical context (Cassel \& Simon, 2004; Cresswell, 2007). The data were collected through documents from various media including youtube videos and extensive in-depth interviews of seven individuals namely Satrio Arismunandar (AJI-Aliansi Jurnalis Independen, Alliance of Independent Journalists, Ex-Kompas and TransTV), Gh (An anynomous RCTI Official), Donist (An anynomous TVRI official), Agus Sudibyo (Media Researcher, Ex-ISAI (Institut Studi Arus Informasi, Information Studies Institute activist and ex-Press Council member in 20102013), Judhariksawan (KPI commissioner), Idi Muzayyad (KPI commissioner), A.S Hikam (Academician and Ex-Minister of Research and Technology under Abdurrahman Wahid's Presidency). Political-economy and mediatization perspective will be critically used to consider historical and contemporary context in data analysis and literature.

\section{Results}

\section{Political-economy of Indonesian Media since the Suharto Era}

Why does understanding the media sector under the New Order politico-economically and historically lead to better mediatization analysis? The corrupt regime of the $\mathrm{New}$ Order could be seen as the main cause of today's colonization of oligarchic power in contemporary Indonesia. Suharto's regime implemented the soviet style in managing information and communication resources and in colonizing people and the political order. The soviet style refers to the practice of controlling media under an authoritarian regime in which media along with any organizations are controlled and forced to serve the authoritarian regime and respect its cronies (Esarey \& Xiao, 2011). The colonization process happened in the interest of the New Order wherein the media and broadcasting sectors were utilized simply as state agents serving the ruling elites and party.

The colonization becomes more dynamic in present day Indonesia as seen in political contestation amongst media, elites, activists, civil society groups, students, and so forth as well as under cartel politics involving oligarchic political parties (Hikam, interview on September $22^{\text {nd }} 2015$ ). This intensified colonization by involving the media's role in politics and society could be noted as the third stage of mediatization of politics and society in which the media hardly played any transitional and dialogical role in accommodating and changing the apex of political logic into media logic of democracy. Media were constrained by the oligarchic elites 'interests in attempting to construct a democratic public opinion but pseudo political reality. Even though the media have hardly enforced their logic regarding freedom of speech, equality, cosmopolitanism, democratic human rights, etc. upon political institutions and society since the arrival of Reformasi in 1998 until today, the media's interaction and penetration over political life became incredibly more important within social and political life under the democratic regime and the prevalence of internet and social media technology. 
The development of the Indonesian media sector is mainly related to historical sociology of the politico-economic power and media ownership under the Suharto era that significantly influenced subsequent media debate, particularly regarding media autonomy which had incredibly transformed into becoming more democratic in search of democracy, polity, and civility during the post-authoritarian Indonesia period (Sen \& Hill, 2007). The media sector has significantly developed and enjoyed freedom of press post-1998 as a result of the struggle and legal achievements of pro-democracy groups, experts, and professionals (Satrio Arismunandar, Ex-Kompas and Trans TV journalist interview on September 19 ${ }^{\text {th }} 2015$ ). The progress could be noted by considering the number of active media, the condition wherein the state no longer monitors and strictly censors the press and any media particularly under the Abdurahman Wahid administration, and the enactment of Press Law No. 40/1999 and the Broadcasting Law No.32/2002, etc. Nevertheless, the media sector has been hindered by market-oriented vision of business interests and politically challenged by uncivilized groups controlled by the elites' interests. In this sense, Heryanto and Hadiz assumed that the media have been relatively liberalized but unprotected (Ariel Heryanto \& Hadiz, 2005).

The broadcasting media, both stateowned and private media outlets, have long developed on its own during the Suharto regime (1965-1998) and was liberalized in post-1998 democracy, but as of current they remain vulnerable to politically vested interests and have yet to become the autonomousprofessional media it is expected to be (Donist, interview on October $\left.21^{\text {st }}, 2013\right)$. TVRI, as an example, has been utilized by Suharto since the beginning of the New Order to propagate state 's interests of developmentalism, Pancasila and anti-communism under military-civilian coalition in certain periods and circumstances (Aspinall, 2005), but it remained to be politicized by the ruling elites toward the 2014 election.

After the political turmoil in 1965, the Suharto regime focused on initiating the national development agendas and using the revenue from the oil boom to implement several extraordinary economic development programs that require political stabilization (Vatikiotis, 2003). The media were consequently considered an effective tool for the regime in safeguarding various interests and development agendas, the media were thus utilized as agent of stabilization by the regime. Later, the media sector was also affected by the successful economic achievements of the regime which subsequently changed political discourse of the media into a commercially significant industry during the 1970s-1980s. Then, Suharto gradually forced any media to become more re-politicized in the 1990s, hand in hand with the rising critical thinking middle class in Indonesia (Sen \& Hill, 2007).

The Suharto regime had been inclined to control and monitor the potentiality of print media criticism since its early days when the broadcasting sector was easily colonized by the regime as state-owned apparatus and had acted as an agent of stability and nationbuilding (McCargo, 2003). The reason is that the press such as newspapers and magazines had independently existed and potentially set political agendas in Indonesia (Sen \& Hill, 2007). For instance, in the late 1960 s some print media such as Indonesia Raya, Harian Kami, Nusantara, and Mahasiswa Indonesia along with intellectuals and students enthusiastically campaigned against corruption and criticized the abuse of power. Similar movements happened when Japanese prime minister, Tanaka visited Indonesia in 1974. Media, students, and politicians seized the moment to criticize Suharto's corruption, cronyism, and economic programs (Aspinall, 2005). As a result of this prolonged political criticism and 
activism, Suharto consequently banned eleven newspapers and one magazine at the time. Suharto finally enforced press restrictions in the 1980s and 1990s by banning three magazines i.e. Tempo, Detik, and Editor in 1994 (Sen \& Hill, 2007).

In contrast to the press media, the state's broadcasters, namely TVRI and RRI, had been preserved as the state's apparatus. TVRI in the 1970s and 1980s were particularly very influential and important in supporting government policies and controlling public opinions (Armando, 2011). TVRI had three main goals under the New Order: firstly, the promotion of national unity and integration; secondly, the promotion of national stability; and thirdly, the promotion of political stability (Kitley, 2000). TVRI had no alternative and it emphasized the primacy of national development in the various economic, social, cultural, and political sectors, the pursuit of cultural and informational autonomy, the support for democracy, and the solidarity with other developing countries. Those functions were based on Suharto's speech on the $24^{\text {th }}$ of August 1982 which stipulated that TVRI as well as RRI are responsible to encourage nationalism, promote unity and integration, build national character and culture, and stimulate people's participation in national development (Sudibyo et al, 2004).

TVRI was expected to be the state's media in the beginning of New Order, nonetheless, TVRI broadcasted programs very well, it respected the public demands at the time, it provided inspiring media contents such as the children's puppet series Si Unyil, the soap opera Rahmat Family, and the news program called Berita Nasional (Kitley, 2000). TVRI seemed to be successfully maintaining their programs because it had been regularly supplied with vast budget allocation and had no competitors. More importantly, TVRI had also remarkably raised substantial revenue from advertising and TV fees alongside the regular allocation of government subsidy (Armando, 2011). Unfortunately, TVRI as a potential democratic public media in the peak of regime performance was being scapegoated by elites 'conflict and regime's interest that led to the critical position. As such, in the annual presidential speech on the $5^{\text {th }}$ of January 1981, Suharto politically asked TVRI to stop advertising and be more concerned on development targets in the early 1980s in front of the DPR (Armando, 2011). At the same time, the oil boom of 1974 and late 1970s confidently encouraged Suharto to force this policy because the regime was able to provide the annual budget for TVRI.

This decision was considered unreasonable for TVRI at the time since the potential business and advertisement income contributed more than 50 percent to its annual revenue which consequently made TVRI to gradually become a professional and autonomous broadcaster in serving the public (Kitlely, 200) and thereby more likely closer to the ideal performance of public-oriented media. By the early 1980s, TVRI had limited budget without advertising and barely provided any interesting programs for the public and it eventually became more dependent on the government. Suharto fully forced TVRI to be both the agent of stability and mouthpiece for the regime agenda rather than improving its potential to be a professional public service broadcaster. This situation also triggered the advent of private television media in the final period of Suharto's reign. Suharto afforded the opportunity for his family and cronies to invest in the media industry. This chance was limited to trusted people. In other words, the private media outlets at the time were established in the hands of cronyistic businessmen oligarch that started to emerge in the late 1980s. The Suharto regime invited investment, involved their families and cronies and concurrently the middle class began to publicly appear in urban areas (Kitley, 2000). 


\section{The Media Industry and Suharto's Cronyism}

What is the impact of the media industry and how did it relate to the rise of the Suharto circle? Private media in Indonesia are the big industry and businesses that target economic profit. The early private media outlets in Indonesia were mostly owned by Suharto's family and cronies. RCTI belonged to Bambang Trihadmodjo, Suharto's third child, at the helm of the Bimantara business group in 1990. The second private channel was SCTV in 1989 wherein eighty per cent of the company shares were controlled by Henri Pribadi, a Chinese businessman and close friend to Suharto's cousin, Sudwikatmono who owned the remaining 20 percent. The third private channel, TPI, was mostly owned by Siti Hardiyanti Rukmana, Suharto's daughter in 1990 (Sen and Hill, 2007).

Agus Sudibyo, a media researcher, exISAI (Institut Studi Arus Informasi, Information Studies Institute) activist and ex-Press Council member in 2010-2013 explained that Suharto had primarily underpinned his family and cronies to manage and gain benefits from private media outlets. In doing so, those media were easily controlled and directed to merely focus on the business agendas rather than political matters (Interview on October $25^{\text {th }}$ 2013). Those media supported the regime and their owners were inclined to get involved in rent seeking activities and be committed to the market rather than democratic role of media. Yet the media privatization of these networks was carried out through cronyism and later on they became trusted oligarchic networks that change day by day. That is why, several private media tended to refuse to pay back their debts to support TVRI as the public broadcaster in post-Authoritarian Indonesia based on a particular agreement in 2002.

Regarding the regime's policy based on this development-liberalization agenda, Haryanto assumed that Suharto's policies seemed to be inconsistent and contradicted with media control. At the one hand, Suharto's cronies exploited media corporations, while on the other, the censorship over the media was still conducted by the Ministry of Information (Haryanto, 2007). However, any policies of the regime regarding the media sector is likely possible because the regime had economic interests and close relationships with the media owners.

Ownership of private media outlets have gradually changed from a simple one under Suharto's era into more complex ownerships called mergers and acquisitions in the PostNew Order era (Nugroho, Siregar and Laksmi, 2012). Under the Suharto era, private media outlets and ownership completely functioned as puppets in serving the authoritarian regime wherein they performed no significant criticism and received more pressures from the public specifically from civil society groups in the media sector. Meanwhile, in post-Suharto Indonesia those private media are regulated by the Press and Broadcasting Law along with their regulatory institutions, namely the Press Council and Indonesian Broadcasting Commission called KPI as well as being controlled by the public and relevant civil society organizations. Nevertheless, media corporations' tendencies seemed slightly similar in terms of being colonized by the elites and political parties, being profit-oriented and having the tendency to overlook the democratic role of media to some extent (A Heryanto \& Hadiz, 2005; Sudibyo, Andre and Aminuddin, 2004). The ownership of private media such as TV networks had evidently facilitated the ruling elite and party to utilize such media for their electoral interests.

\section{Media Reform Brings Uncertainty in the Post-New Order Era}

Why has media reform following Reformasi brought about ambiguity? There is serious truth on the lack of insight into transformation 
of media ownership and its implication without understanding of the transitional period. Indeed, the media landscape changed after Suharto`s downfall. Habibie consequently came to power and promoted media reform and democracy to open society (Ricklefs, 2001) amidst the contestation of status quo elites (Robinson and Hadiz, 2004). Meanwhile, civil society organizations advocated the media (Kitley, 2003) and called for civil collaboration among student movement activists, NGO activists, intellectuals, media journalists, etc. (Sudibyo, 2001).

In the middle of elites ' contestation and criticism, Habibie promoted Press Law No. 40/1999. As a result, the media dramatically transformed into a double-edged sword of market-oriented (Sudibyo, 2009) and publicoriented media in Indonesia`s Post-1998 period (Nugroho et al, 2012). This regulation not only augmented media freedom and functional public sphere, but also provided legitimacy to professionally regulate the media industry in order to be more committed to the public. Subsequently, several media outlets and organizations were established under the Habibie regime as part of a national media reform and they developed from simple into complex businesses.

The minister of information, Muhammad Yunus, during the Habibie era attempted to truly create milestone reforms by "revoking the printing and publication permit called SIUPP, issuing over twelve hundred (1200) new print licenses, and approving the issue of five new commercial television licenses and more than nine hundred new commercial radio licenses, twenty-four officially recognized journalists' association. Then, commercial radio stations' obligation to relay state news was reduced to three bulletins a day. Radio and television stations reveled in the opportunity to produce their own news bulletins and present openly critical analyses of current affairs. Finally, during transitional period in 1998-9 both radio and television played an increasingly important role in mediating aspirations for greater democracy in Indonesia (Kitley, 2003)."

The mainstream media enjoyed this situation. Private televisions such as RCTI, SCTV, TPI became more powerful after becoming a more commercialized media. Two years later, Trans TV, Metro TV, TV Global, TV-7, and LATIVI had finally emerged. This time could be noted as the era when private television networks became more developed and started to play roles in the new democratic public sphere. In the meantime, the performance of TVRI in the Post-New Order period as a potential public-oriented media has been left behind by the other private-commercial networks in terms of attracting the public. CSOs in the media and broadcasting sector hoped that TVRI would become a more powerful and independent broadcaster promoting democratic debate and public interests. But that role has yet to be realized by TVRI and it has even become more dependent on the government budget that seemed to be more political in the DPR.

According to Gh, an RCTI official, most broadcasters should politico-economically adapt to the current situation as a result of the rise of information era. Audiences and social organizations preferences have significantly changed including their sensibility and expectations toward media programs (Interview on October $27^{\text {th }} 2013$ ). Private-commercial television networks with significant income revenues from advertising such as RCTI could provide programs that meet the audience needs. On the other hand, TVRI, after having lost its budget since Suharto's era until the present day has been struggling to maintain its organization. Donist, a TVRI official, mentioned that TVRI would on occasion run out of budget to produce good programs. This is why TVRI frequently broadcasts mere reruns of its programs. Ironically, commercial TV has become more developed today while TVRI remains stagnant and in need 
of innovation to survive and compete with others (Interview on October 21 $1^{\text {st }}$ 2013).

After the implementation of Broadcasting Law in 2002, according to article 13 (2), TVRI was transformed into a Lembaga Penyiaran Publik or LPP (Public Broadcasting Service) in order to strengthen its role in promoting national interests and democratic life. TVRI was previously a Perusahaan Jawatan (Perjan, Corporate Office) through the government regulation of PP No.36/2000 in which TVRI coordinated with the Minister of Finance. Then it changed into a Perseroan Terbatas (Limited Company) through PP No. 9/2002 in order to return its advertisement program for profit, in which TVRI coordinated with the Minister of BUMN (Badan Usaha Milik Negara, State-Owned Enterprises) (Sudibyo et al, 2004). However, even with TVRI's status as a Public Broadcasting Service promoting internal reform and enabling at least 15 percent for advertising programs as stipulated in the Broadcasting Law of 2002, the income from advertising remained insufficient to operate TVRI programs and TVRI depends heavily on the frequently unpunctual government budget
(Donist, interview October 21 ${ }^{\text {st }}$ 2013).It seems that TVRI is unable to seize its time to become a great public broadcaster.

Amidst the complicated media democratization agenda in the long term, private-commercial TV networks have focused more on business profit (Sudibyo et al, 2004), whilst TVRI as a public-oriented media appeared to be withering, and this is the reason why civil society actors need to practically observe the media sector and be engaged in improving potential media system as well as promoting democratic media policy, institutional reform, and media advocacyliteracy movements.

The following table shows the economic landscape of Indonesian national television networks in 2011.

From the six groups of ten private national television networks above, "MNC group appears to be the most powerful broadcasters with the highest share of 36.7 percent consisting of RCTI, Global TV, and MNCTV. Whilst TVRI has a market share of only 1.4 percent of the total share. Yet, the concentration of television network ownership

Table 1.

The Landscape of Indonesian National Television

\begin{tabular}{lclcc}
\hline \multicolumn{1}{c}{ TV Channel } & First on Air & \multicolumn{1}{c}{ Status } & \multicolumn{2}{c}{ Market Share \% } \\
TVRI & 1962 & State/Independent & 1.4 & 1.4 \\
RCTI & 1987 & Merged (MNC) & 19 & \\
Global TV & 2001 & Merged (MNC) & 5.1 & 36.7 \\
MNCTV & 1990 & Merged (MNC) & 12.6 & \\
(Formerly TPI)+ & & & 17.3 & \multirow{2}{*}{31.5} \\
SCTV & 1989 & Merged (EMTEK)+ & 14.2 & \multirow{2}{*}{18.5} \\
Indosiar & 1995 & Merged (EMTEK)+ \\
Trans TV & 2001 & Merged (TransCorp) & 12.1 & \\
Trans 7 & 2001, & Merged (TransCorp) & 6.4 & \\
TV One & re-launch in 2006 & & & \\
(formerly Lativi) & 2001 & Merged (Bakrie/MM Group)+ & 4.5 & \\
ANTV & 1993 & Merged (Bakrie/MM Group)+ & 4.2 & \\
& & & & \\
METROTV & 2000 & Media Group/Independent & 1.9 & 1.9 \\
\hline
\end{tabular}

Source: Lim (2011) 
in Indonesia results from the practice of mergers and consolidation of media businesses as a logical consequence of media liberalization, but it is partly not favorable in terms of media democratization (Lim, 2011)."In other words, TVRI is supposedly more engaged in promoting sustainable media democratization, but its economic power and resources are completely weak. As such, the public depends more on the kindness of private media outlets to democratize the public sphere.

In that sense, Lim emphasized the probable negative impact of such private media ownership in the long term toward media democratization due to a lack of competition. The small amount of media companies firmly dominate the media industry and they have created a media oligopoly that contributed to biased political contents (Lim, 2011). However, ownership interventions over media organizations and contents mostly happen at the national level in which the media industry and conglomeration massively operates. At the local level, media interference remains unconcerned about media conglomeration, instead it is apparently being operated by local politicians in hegemonic cooperation with the media.

The biased media intensively appeared during Indonesian elections at local and national level since 2009 until 2014. Indeed, some scholars are more concerned on real media freedom today in which Indonesia still needs more of especially those relating to political issues. However, a more important issue is the recent situation regarding media performance upon gaining media freedom under complex oligarchic politics. This is also the rational argument for the presence of KPI, which should be supported by CSOs in the media sector, in regulating and observing the media industry in Post-Authoritarian Indonesia. In the meantime, internet-based alternative media which essentially are online and social media have emerged to support
CSOs `activism in carrying out present offline and online functions by criticizing the ruling elites and promoting democracy throughout all sectors in both the virtual and real world in contemporary Indonesia.

\section{Media Democratization and KPI`s Role in Controlling Undemocratic Tendencies of Private Media}

Why couldn't KPI control the private media? The main reason behind political parties ' colonization toward media life in postSuharto Indonesia is the oligarchic networks of wealthy politicians that occupied political parties' demands to control political life since they have become more powerfully organized. At the same time, this colonization operates with the lack of media democratization carried out by KPI (Komisi Penyiaran Indonesia, Indonesian Broadcasting Commission) along with civil society.

Nevertheless, KPI to some extent has already played a significant role in reinforcing the democratic role of the media particularly in terms of contents and ownership of broadcasting media. This could potentially foster media supremacy as the fourth estate of democracy wherein KPI mediates media logic in controlling political life and society. KPI has contributed in the transitional third stage of mediatization of politics in Indonesia in which the media are supposedly striving to influence and transform politics and culture to be more democratic.

KPI is an independent institution as stipulated by the Broadcasting Law 32/2002. It is established at the national and local level to promote media democratization in PostNew Order Indonesia. Public regulations, especially regarding the broadcasting sector, have been regulated in the broadcasting law but a number of revisions remain necessary. Judhariksawan and Idi Muzayyad, KPI's commissioners, explained that the complex political circumstances related to business 
and elites ' interests make it difficult to have the law fully implemented as of current. KPI has indeed attempted to negotiate with all involved stakeholders particularly the Ministry of Information and Communication, private media and decision makers during the ongoing revision of this law in order to evaluate the law and prepare for the next media democratization agendas (Interview on September 19 ${ }^{\text {th }}$ 2013).

The table 2 below shows the main challenges of KPI in media democratization as stipulated by the Broadcasting Law 32/2002.

In summary, KPI is faced with three challenges. First, KPI has no full authority over media license of broadcasters which significantly affects its relations toward media conglomeration. Second, KPI could barely manage media monopoly and cross-ownership because not only does KPI operate based on a weak rule of law and legitimacy, but those media monopoly and cross-ownership are subtly backed up by political parties and their elites. Third, KPI could not insist national private media to establish NSS (Network Station System) considering coverage areas and distributing knowledge and capacities because those media argue that they do not have the resources to establish network stations in each province. However, the reasoning behind the media's reluctance and lack of enthusiasm to democratize the media sector in the Post-New Order era is because they gain a huge sum of money from the prevailing system and at the same time their position is rather strong being backed up by oligarchic politicians.

According to Gh, an RCTI official, the Broadcasting Law based regulation is not relevant and suitable to private television networks' interests. In truth, this law restricts private television networks to gain greater profit and enforces them to be more fully concerned on serving the public (Interview on October $27^{\text {th }}$ 2013). KPI, based on the Broadcasting Law, needs to strictly regulate the private television networks to adapt to democratic values implied in the law such as diversity of owners and contents that accommodate public demands in terms of social, cultural, and economic contents at the local and national level.

In fact, private television networks have not established the Sistem Siaran Berjaringan (National Station System) as stipulated by the broadcasting law in which private national media organizations such as RCTI, SCTV, TV One, etc. should establish local stations, build their infrastructure, and provide human resources in each province in Indonesia. Even worse, private television networks have yet to respond completely to any public criticism regarding media contents that contradict with social values and political rules such as pornography, mystic-oriented movies/programs or political campaign by political parties and figures. Article 5 provides information, to some extent, regarding the meaning of media democratization in the law advocated by KPI and CSOs in the media sector:

\section{Table 2.}

Article 5 of the Broadcasting Law

No. 32/2002

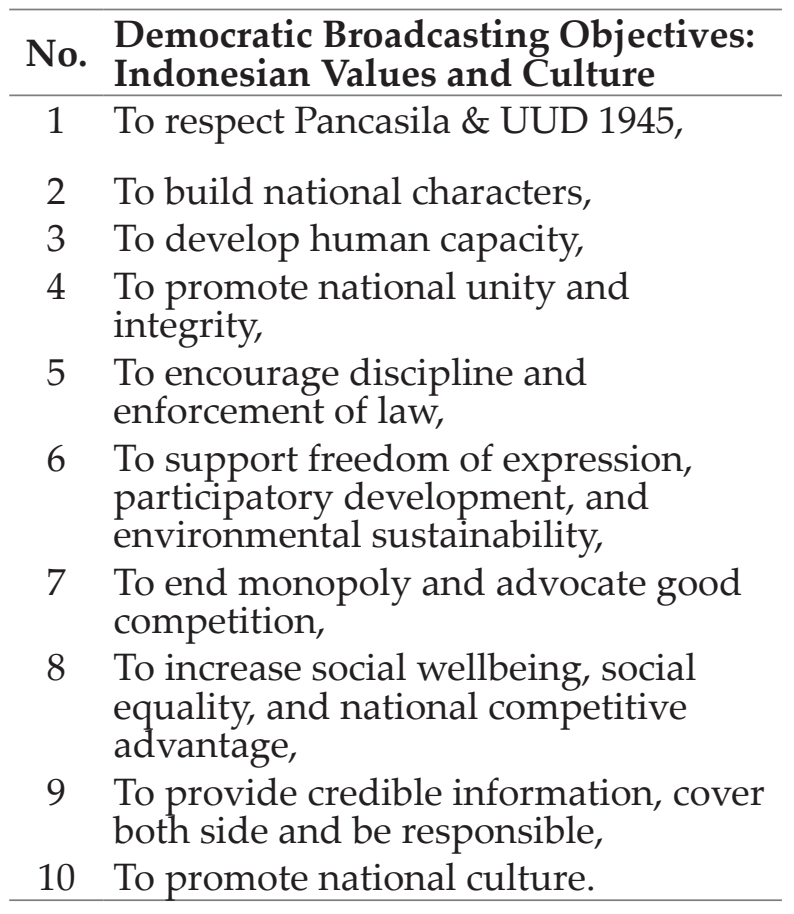

Source: Author modified from The Broadcasting Law No 32/2002 Article 5 
KPI has been truly supported by Civil Society Organizations (CSOs) to promote the broadcasting law, but their support is still incapable of compelling private media outlets to fully comply to it. The reason for this is that KPI has no legal standing to being a powerful regulator that imposes sanctions such as in issuing warnings and stopping media licenses of any private television network if they do not adhere to the law. Thus, reformist politicians are still lobbying DPR to revise that law while CSOs in the media sector are still finding it difficult advocating the public interests and promoting media literacy due to financial issues. It is without a doubt that they are in need of a lot more support from the grassroots community.

\section{Conclusion}

Mediatization of politics is proven to be operating in Indonesia under political and informational circumstances. Indeed, the politicoeconomy analysis based on the school of critical theory is the most useful and provides the deepest perspective in understanding social and political phenomena including the media sector by mainly identifying and recognizing that media conglomerations today are owned, maintained, and utilized by oligarchic political parties rooted in the legacy of the Suharto's authoritarian regime. According to Hadiz (V. R. Hadiz, 2004, 2008; V. Hadiz, 2003; A Heryanto \& Hadiz, 2005), the structure of Indonesian politics remains strongly imbued by the New Order legacy.

However, a pluralist based mediatization perspective will most likely broaden and sharpen the public's horizons in interpreting media trends related to political realms in the Post-Authoritarian era. At the same time, it optimistically calls upon the media to play its role as one of the pillars of democracy in Indonesia even under the mounting challenges of transitional justice, corruption, oligarchy and cartel parties. This mediatization process without a doubt shows several lens of media relationship with complex oligarchic power under varying situations in Indonesia's post1998 democracy, such as the business media's colonization, contestation over media policy, and the advent of alternative internet media that goes beyond prevailing boundaries in contemporary Indonesian politics.

Moreover, mediatization of politics in Indonesia could clearly be explained through the role of KPI in the current mediatization era. This article started from a political economy analysis under Suharto's Era and continued to explain how KPI played a role to determine and mediate the complex interactions between the media and political actors in Indonesia at different levels and situations. KPI is undeniably not a perfect institution to control political parties, elites and their private media, but it partly contributes to promoting media democratization in post reform Indonesia based on the Broadcasting Law 32/2002. Alternative online and social media also play a role in supporting deliberations of online democracy as well as in criticizing political parties, elites, and their dominant private media. The above activities completely took place under complex media-politics relations in the post New Order era. The role of KPI in regulating the media sector proved the elusive existence of a contestation between political logic and media logic under today`s oligarchic networks. Traditional media remains significant despite having been hijacked and weakened by political parties and their elites, whereas KPI at the national level is still promoting media logic. Alternative media is needed since they are trying to offer alternative media logic beyond mainstream media and political logic of oligarchic power in post-Authoritarian Indonesia.

\section{References}

Arifuddin, M.T. (2014). Representasi Politik Opini Publik terhadap Pemilukada Sumatra Barat

2010 pada Koran Singgalang dan Program Sumbar Satu. Jurnal Komunikasi UII 17, 39-41. 
Armando, Ade. (2011). Jakarta di atas Indonesia: Kisah Kegagalan Siaran Berjaringan. Yogyakarta: Bentang.

Anderson, B. (2006). Imagined Communities [electronic resource] : Reflections on the Origin and Spread of Nationalism/Benedict Anderson. ACLS Humanities E-Book. http:// doi.org/10.1080/14725843.2011.556797.

Aspinall, E. (2013). Popular Agency and Interests in Indonesia's Democratic Transition and Consolidation. Indonesia, 96(1), 101-121.

http://doi.org/10.1353/ind.2013.0021.

Aspinall, Edward. (2014). Demokrasi Indonesia dalam Bahaya. New Mandala. http:// asiapacific.anu.edu.au/newmandala/.

Aspinall, Edward. (2005). Opposing Suharto: Compromise, Resistance and Regime Change in Indonesia. California: Stanford University Press.

Brewin, M. (2002). Journalism and Democracy: An Evaluation of the Political Public Sphere, by Brian McNair. The Information Society Vol. 18.

http://doi.org/10.1080/01972240252818234.

Castells, M. (2010). The Rise of the Network Society. Massachusetts: Blackwell Publishing (Vol. I). http://doi.org/10.2307/1252090.

Esarey, A., \& Xiao, Q. (2011). Digital Communication and Political Change in China. International Journal of Communication, $5,22$.

http://doi.org/1932-8036/20110298.

Hadiz, V. (2003). Reorganizing Political Power in Indonesia: A Reconsideration of socalled "Democratic Transitions." The Pacific Review, 16(4), 591-611. http://doi.org/10.108 0/0951274032000132272.

Hadiz, V. R. (2004). Decentralisation and Democracy in Indonesia: A Critique of Neo-Institutional Perspectives. Development and Change, 35(4), 697-718. http://doi. org/10.1111/j.0012-155X.2004.00376.x.

Hadiz, V. R. (2008). Understanding Social Trajectories: Structure and Actor in the
Democratization Debate. Pacific Affairs, 81 (4), 527-536.

Harris, Dan and Marta Forresti. (2011). Indonesia `s Progress on Governance: State Cohesion and trategic Institutional Reform. London: ODI.

Haryanto, Ignatius. (2007). Ketika Sensor Tak MatiMati. Jakarta: Yayasan Kalam Utan Kayu.

Heryanto, A., \& Hadiz, V. R. (2005). PostAuthoritarian Indonesia. Critical Asian Studies, 37(2), 251-275.

http://doi.org/10.1080/14672710500106341.

Heryanto, A., \& Hadiz, V. R. (2005). Postauthoritarian Indonesia - A comparative Southeast Asian Perspective. Critical Asian Studies, 37(2), 251-275. http://doi. org/10.1080/14672710500106341.

Hjarvard, S. (2008). Mediatization of Society. A Theory of the Media as Agents of Social and Cultural Change. Nordicom Review, 29(2), 105-134.

http://doi.org/10.4324/9780203155363.

Kitley, Philips. (2000). Television, Nation, and Culture in Indonesia. Athens: Ohio University Center for International Studies.

Kitley, Philips. (2003). Television, Regulation and Civil Society in Asia. London: Routledge.

Laclau, E., \& Mouffe, C. (1988). Post-Marxism and the New Social Movements Hegemony and Socialist Strategy: Towards a Radical Democratic Politics. Theory and Society, 17(6), 885-900.

http://doi.org/10.1093/fs/54.3.412.

Lim, Merlyna. (2014). Bridging Women Rights Networks: Analyzing Interconnected Online Collected Actions. Journal of Global Information Management 22: 1-20.

Lim, M. (2013). Many Clicks but Little Sticks: Social Media Activism in Indonesia. Journal of Contemporary Asia, 43(4), 636-657.

http://doi.org/10.1080/00472336.2013.769386.

Lim, Merlyna. (2012). The League of Thirteen Media Concentration in Indonesia.Arizona: Arizona State University \& The Ford Foundation. 
Lim, Merlyna.(2011). @Crossroads: Democratization and Corporatization of Media in Indonesia. Arizona: Arizona State University and Ford Foundation.

Lippman, W. (1922). Public Opinion. American Political Thought.

MAZZOLENI, G., \& SCHULZ, W. (1999). "Mediatization" of Politics: A Challenge for Democracy? Political Communication, 16 (3), 247-261.

http://doi.org/10.1080/105846099198613.

McCargo, Duncan. (2003). Media and Poltics in Pacific Asia. London: Routledge Curzon.

Mietzner, Marcus. (2015). Reinventing Asian Populism: Jokowi's Rise, Democracy, and Political Contestation in Indonesia. Hawai $\mathrm{i}$ : The East-West Center.

McNair, B. (2007). An introduction to political communication/Brian McNair. Communication and society. Retrieved from: https://ezp.lib. unimelb.edu.au/login?url=https://search. ebscohost.com/login.aspx?direct=true\& $\mathrm{db}=\mathrm{ca}$ t00006a\&AN=melb.b3106938\&site $=$ eds-live.

Norris, A. (2006). Ernesto Laclau and the Logic of "The Political." Philosophy \& Social Criticism, 32, 111-134.

http://doi.org/10.1177/0191453706059848.

Nugroho, Y. (2007). Does the internet transform civil society? The case of civil society organisations in Indonesia. PQDT - UK $\mathcal{E}$ Ireland. The University of Manchester (United Kingdom). Retrieved from

http://search.proquest.com/docview/89872598 6 ? accountid=13771.

Nugroho, Y. (2008). Adopting Technology, Transforming Society: The Internet and the Reshaping of Civil Society Activism in Indonesia. Australian Journal of Emerging Technologies and Society, 6(2), 77-105.

Nugroho, Yanuar and Sofie S. Syarif. (2012). Beyond Click-Activism? New Media and Political Processes in Contemporary Indonesia. Berlin: Fesmedia Asia.

Nugroho Y., Fajri M. Siregar, D. Putri, and A. Laksmi. (2012). Mapping the Landscape of the
Media Industry in Contemporary Indonesia. Jakarta: CIPG and HIVOS.

Robinson, Richard and Vedi R. Hadiz. (2004). Reorganising Power in Indonesia the Politics of Oligarchy in an Age of Market. London: Routledge Curzon.

Ricklefs, M.C. (2001). A History of Modern Indonesia since C. 1200. Hampshire: Palgrave.

Schulz, W. (2004). Reconstructing Mediatization as an Analytical Concept. European Journal of Communication, 19 (1), 87-101.

http://doi.org/10.1177/0267323104040696.

Sen, Krishna \& David T. Hill. Media, Culture, and Politics in Indonesia.Jakarta: Equinox Publishing, 2007.

Stromback, J. (2008). Four Phases of Mediatization: An Analysis of the Mediatization of Politics. The International Journal of Press/Politics, 13(3), 228-246. http:// doi.org/10.1177/1940161208319097.

Strömbäck, J., \& Dimitrova, D. V. (2011). Mediatization and Media Interventionism: A Comparative Analysis of Sweden and the United States. The International Journal of Press/Politics, 16(1), 30-49.

http://doi.org/10.1177/1940161210379504.

Stromback, J., \& Van Aelst, P. (2013). Why

Political Parties Adapt to the Media:

Exploring the Fourth Dimension of Mediatization. International Communication Gazette, 75(4), 341-358. http://doi. org/10.1177/1748048513482266.

Sudibyo, Agus. (2001). Politik Media dan Pertarungan Wacana. Yogyakarta: LKIS.

Sudibyo, A., T. Andre and I. Aminuddin. (2004). Ekonomi Politik Media Penyiaran Yogyakarta: LKiS.

Sudibyo, Agus. (2009). Kebebasan Semu: Penjajahan Baru di Jagad Media. Jakarta: Kompas.

Vatikiotis, Michael R.J. (2003). Indonesian Politics under Suharto the Rise and Fall of the New Order. New York: Routledge. 